\title{
A new approach to teaching general and inorganic chemistry
}

\section{Bakhtiyor YODGOROV 1}

Chirchik State Pedagogical Institute

\begin{tabular}{l} 
ARTICLE INFO \\
\hline Article history: \\
Received April 2021 \\
Received in revised form \\
20 April 2021 \\
Accepted 15 May 2021 \\
Available online \\
25 June 2021 \\
\hline
\end{tabular}

\section{Keywords:}

information communication technologies,

general and inorganic

chemistry,

electronic laboratory work;

electronic educational-

methodical complexes;

electronic tests; educational

films, video lectures,

electronic textbooks.

\section{ABSTRACT}

Traditional means of teaching and supervising the training of chemistry students should be updated through the introduction of information and communication technologies. The following information communication technologies are used in the educational process: electronic educational and methodological complexes, electronic textbooks, video lectures, animations; electronic laboratory and practical work, didactic tests, electronic reference books (cases, projects, organizers), etc. It is very important to use information communication technologies in teaching general and inorganic chemistry. The use of new interactive teaching technologies has advantages over traditional methods.

There are also some features of the use of information communication technologies in teaching general and inorganic chemistry. The article provides a detailed analysis of the use of information communication technologies. This allowed the author to conclude that the updating of traditional teaching aids in teaching a course in general and inorganic chemistry covers the entire educational process of teaching.

2181-1415/CC 2021 in Science LLC.

This is an open access article under the Attribution 4.0 International (CC BY 4.0) license (https://creativecommons.org/licenses/by/4.0/deed.ru)

\section{Umumiy va anorganik kimyoni o'qitishga yangicha yondoshuv}

\footnotetext{
Kalit so'zlar:

axborot-kommunikatsiya texnologiyalari, umumiy va noorganik kimyo, elektron testlar, elektron laboratoriya ishlari, elektron o'quv-uslubiy majmualar,
}

\section{ANNOTATSIYA}

Axborot-kommunikatsiya texnologiyalarini joriy etish orqali kimyo bo'yicha talabalarni o'qitish va o'qitishning an'anaviy usullari yangilanishi kerak. Ta'lim jarayonida quyidagi axborotkommunikatsiya texnologiyalari qo'llaniladi: elektron o'quvuslubiy majmualar, elektron darsliklar, video ma'ruzalar, animatsiyalar; elektron laboratoriya va amaliy ishlar, didaktik testlar, elektron ma'lumotnomalar (ishlar, loyihalar, tashkilot-

\footnotetext{
${ }^{1}$ Senior lecturer, Chirchik State Pedagogical Institute, Tashkent Region, Chirchik, Uzbekistan.
} 
o'quv filmlari; video ma'ruzalar, elektron darsliklar. chilar) va boshqalar umumiy va noorganik kimyo fanlarini o'qitishda axborot-kommunikatsiya texnologiyalaridan foydalanish juda muhimdir. O'qitishning yangi interaktiv texnologiyalaridan foydalanish an'anaviy metodlardan afzalliklarga ega.

Umumiy va noorganik kimyoni o'qitishda axborotkommunikatsiya texnologiyalaridan foydalanishning ba'zi xususiyatlari ham mavjud. Maqolada axborot-kommunikatsiya texnologiyalaridan foydalanish bo'yicha batafsil tahlil berilgan. $\mathrm{Bu}$ muallifga umumiy va noorganik kimyo kursini o'qitishda an'anaviy o'quv vositalarini yangilash o'qitishning butun o'quv jarayonini qamrab oladi degan xulosaga kelish imkonini berdi.

\section{Новый подход к преподаванию общей и неорганической химии}

Ключевые слова:
информационно-
коммуникационные
технологии,
общая и неорганическая
химия,
электронные
лабораторные работы,
электронные учебно-
методические комплексы;
электронные тесты,
обучающие фильмы,
видеолекции,
электронные учебники.

\section{АННОТАЦИЯ}

Традиционные средства обучения и контроля за обучением студентов-химиков должны быть обновлены путем внедрения информационных и коммуникационных технологий. В учебном процессе используются следующие информационные коммуникационные технологии: электронные учебнометодические комплексы, электронные учебники, видеолекции, анимации; электронные лабораторные и практические работы, дидактические тесты, электронные справочники (кейсы, проекты, органайзеры) и др. Очень важно использовать информационные коммуникационные технологии в преподавании общей и неорганической химии. Использование новых интерактивных технологий обучения имеет преимущества перед традиционными методами.

Также есть особенности использования информационнокоммуникационных технологий в обучении общей и неорганической химии. В статье представлен подробный анализ использования информационных коммуникационных технологий. Это позволило автору сделать вывод о том, что обновление традиционных учебных пособий при преподавании курса общей и неорганической химии охватывает весь учебный процесс обучения.

Today, there is an acute issue of updating traditional teaching methods, through the use of information technology. This is especially relevant in the process of training future teachers. However, in the process of teaching a number of fundamental disciplines, including chemistry, such innovations encounter a number of difficulties. Among them there is the lack of development of the relevant teaching materials, and the unpreparedness of teachers for the widespread use of new teaching methods, instead of traditional ones, and high mathematical complexity, requiring appropriate software and graphic presentation of the material. But, despite these and other difficulties, attempts are being made to introduce information technologies into the process of teaching the 
discipline "General and inorganic chemistry". This discipline is quite difficult to study, requires a large amount of independent work of students, therefore the development of modern computer teaching methods seems to be especially relevant.

Information technologies used in the learning process can be divided into several types. Among them there are electronic textbooks, lectures, notes, electronic laboratory and practical work, simulators, encyclopedia reference books, testing technologies.

Let's consider how information and communication technologies are applied in the process of teaching "General and Inorganic Chemistry". N.G. Gureev [1] notes that the complex and electronic textbook "General and inorganic chemistry" performs new roles and functions and can simultaneously be a theoretical and practical assistant in independent work, which means that it significantly improves the formation of the intellectual ability of the student and increases the learning efficiency.

The authors of [1] have accumulated a fairly large amount of information and methodological material using computer technologies and have begun the development of an electronic textbook. In works $[2,3,4,5]$, considering the problem of innovative technologies in the process of teaching "General and inorganic chemistry", he also notes the huge role of information and communication technologies. In this regard, for students studying the discipline "General and inorganic chemistry", a didactic complex of information and communication support of the discipline has been created. It includes a database necessary for completing two homework assignments and five laboratory works in a computer workshop, as well as a set of other didactic tools and methodological materials that ensure the educational process. The didactic complex also includes: a work program of the discipline, a lecture course outline, a set of tasks with examples of solutions for each module, control questions and tasks for sections of the lecture course with elements of scientific and technical creativity, electronic versions of guidelines for laboratory work. Thus, working in the laboratory, students have all the necessary educational material. T.L. Anisova [6] suggests using MS Excel to solve problems in chemistry. The paper shows an example of solving a problem in chemical kinetics. It should be noted that the entire process of solving the problem is carried out by the students themselves, i.e. the program acts only as a tool, and ready-made forms and already developed information environments are not offered. N.V. Zhukova [7] reports on the development of an electronic test simulator in chemistry, containing six meaningful blocks: "Solutions of electrolytes".
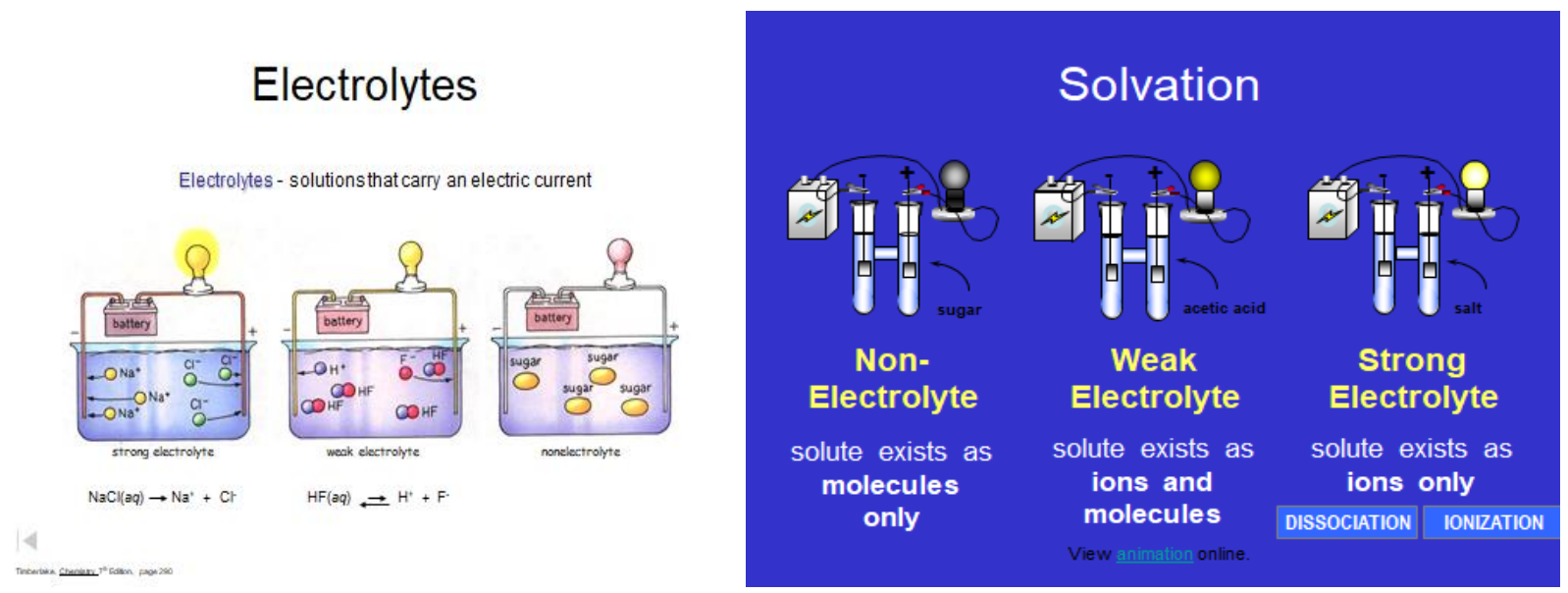
Each block consists of theoretical part, revealing the main issues of the block; simulator tasks with a detailed solution; questions-simulators, which are test tasks with feedback; a control test designed to monitor students' knowledge.

In addition, the student has all the reference material necessary for solving tasks. G.M. Kurunin and G.M. Bondareva write about the use of electronic testing in teaching chemistry: the use of test items in combination with other types of testing is an effective tool that stimulates the preparation of students for each lesson and increases motivation for the subject under study $[8,9,10]$.

Thus, at present, in the process of teaching chemistry, various electronic teaching aids are quite actively used and attempts are being made to introduce electronic practical and laboratory works.

At the Department of Chemistry of the Chirchik State Pedagogical Institute, information technologies are also being introduced into the educational process. For the successful development of the discipline "General and inorganic chemistry", elements of electronic educational and methodological complexes have been developed for students enrolled in undergraduate programs in specialties: - 5110300 "General and inorganic chemistry" [10]. When constructing the complexes, a multi-level modular principle was applied, because it is known that a well-structured complex not only provides quick and convenient access to educational materials, but also helps to plan the development of the course and contributes to more rhythmic and efficient student work during the semester.

All lecture material in electronic form is included the educational and methodological complex of the discipline and is issued to students, which contributes to the successful development of the course.

The lecture course is conducted using electronic presentations shown on a projector. This allows:

- to visualize mathematical formulas, use a large and clear font, which makes it easier for students to understand and speeds up the process (compared to using a traditional board);

- show portraits of scientists, accompanying it with a short story, which increases interest in classes;

- show pictures and graphics with animation - this improves perception and memorization of addictions, promotes concentration of students' attention.

For some sections of the course "General and inorganic chemistry" videos and anemolections were developed. In addition, to increase the motivation to study "General and iInorganic chemistry", a collection of slides "History of chemistry" was created, which in a vivid and entertaining form tells about the period of the formation of chemical science, which preceded the appearance of chemistry. The prerequisites for the emergence of chemistry, the features of this process are shown, it is told about the outstanding scientists who contributed to the formation of this science, and the basic quantitative laws that formed its basis.

When working in practical classes, special presentations are used: they are composed in such a way that the formulas necessary for solving problems appear gradually, at a speed set by the teacher. This contributes to the flow dialogue with the student, gives the student time to think about the problem, and not write off everything from the screen. 

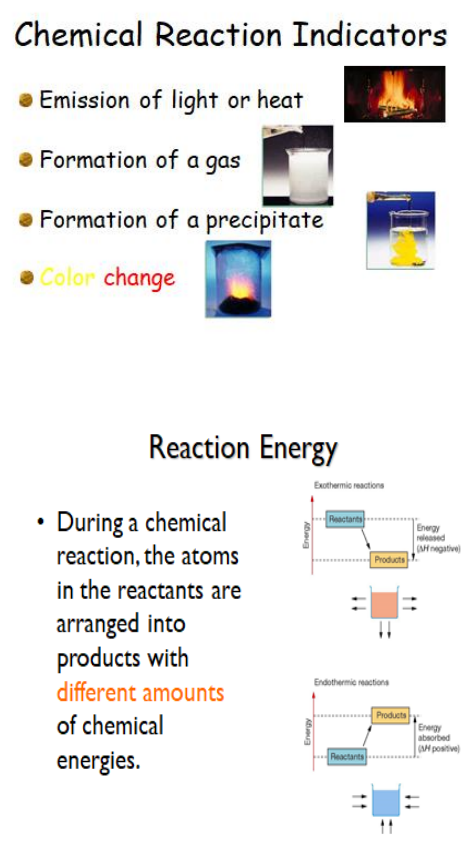

Chemical Reactions

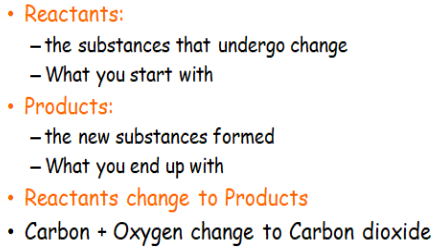

Exothermic

- The total chemical energy of the products is less than the energy of the reactants.

- the difference in energy is released into the environment, often as heat energy.

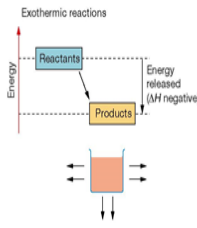

Chemical Energy

The chemical energy of a substance is the sum of its potential energy (stored energy) and kinetic energy (energy of movement). These energies result from such things as:

- Attractions between electrons and protons

- Repulsions between nuclei

Repulsions between electrons

Movement of electrons

Vibrations of and rotations around bonds

\section{Exothermic Reactions}

- Magnesium + Hydrochloric acid
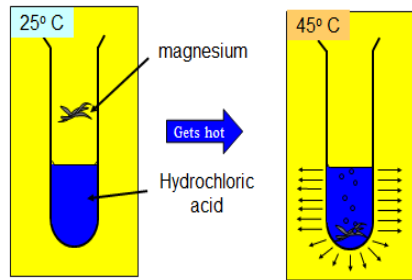

These Excel-based programs allow the student to make calculations much faster than manually. In addition, in the programs, before directly the calculations, all the necessary formulas are given, there are explanations of the symbols, in these formulas included, the approximate graphical dependencies of the studied properties are shown. Such a repetition of theoretical material undoubtedly contributes to a better assimilation of it.

The use of these programs is possible both in the staff computer hall of the department and on a home staff computer.

For independent work of students when doing homework and preparing for intermediate control, there are teaching aids with detailed explanations for solving problems in chemistry $[11,12,13]$.

The use of information technology in laboratory studies includes entrance computer testing and electronic laboratory work, which are carried out along with experimental laboratory work.

Input computer testing (remove repetition before laboratory work) allows you to assess the student's readiness to perform laboratory work. Currently, the department uses MyTestX for testing - a system of programs (student testing program, test editor and results journal) for creating and conducting computer testing, collecting and analyzing results, giving marks according to the scale indicated in the test. The tests compiled in this program for the disciplines of the department are based on different types of tasks: single or multiple choice, establishing the order; establishing compliance; an indication of the truth or falsity of the statements given. 


\section{What is a reaction mechanism?}

The step-by-step sequence of reactions for a chemical reaction.

A step-by-step listing of ingredients.

A list of the reactants in a reaction.

A list of the products in a reaction.

3.What does the $m$ stand for in the rate law equation?

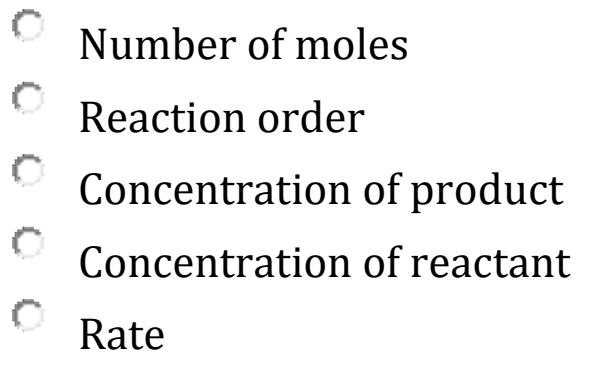

2.What makes the statement 'the presence of a catalyst will slow down a reaction' incorrect?

A catalyst will increase the rate of reaction by raising the amount of energy dedicated to fueling the process.

A catalyst actually increases the rate of reaction by its very introduction into a slow process.

A catalyst actually increases the rate of reaction by lowering the amount of energy needed to start the process.

A catalyst will either increase or decrease the rate of reaction based on what type of material is used.

\section{What is the rate-determining step?}

The slowest step in the reaction

The step that determines the reaction

The overall rate of the reaction

The fastest step in the reaction

Electronic laboratory work has several advantages over experimental:

1. Since they are not directly related to reagents, they can simulate the work with substances that cannot be used in a student's workshop due to safety precautions, for example, use methanol, benzene, etc.

2. Sometimes electronic laboratory work simulates the use of high-temperature devices, which also cannot be implemented in a student laboratory workshop.

3. Electronic labs are often based on data that goes far beyond the time allotted for lab work and equipment that is not available in the lab.

Methodological instructions for laboratory work are available in printed and electronic form, some of the works are combined $[14,15,16,17]$.
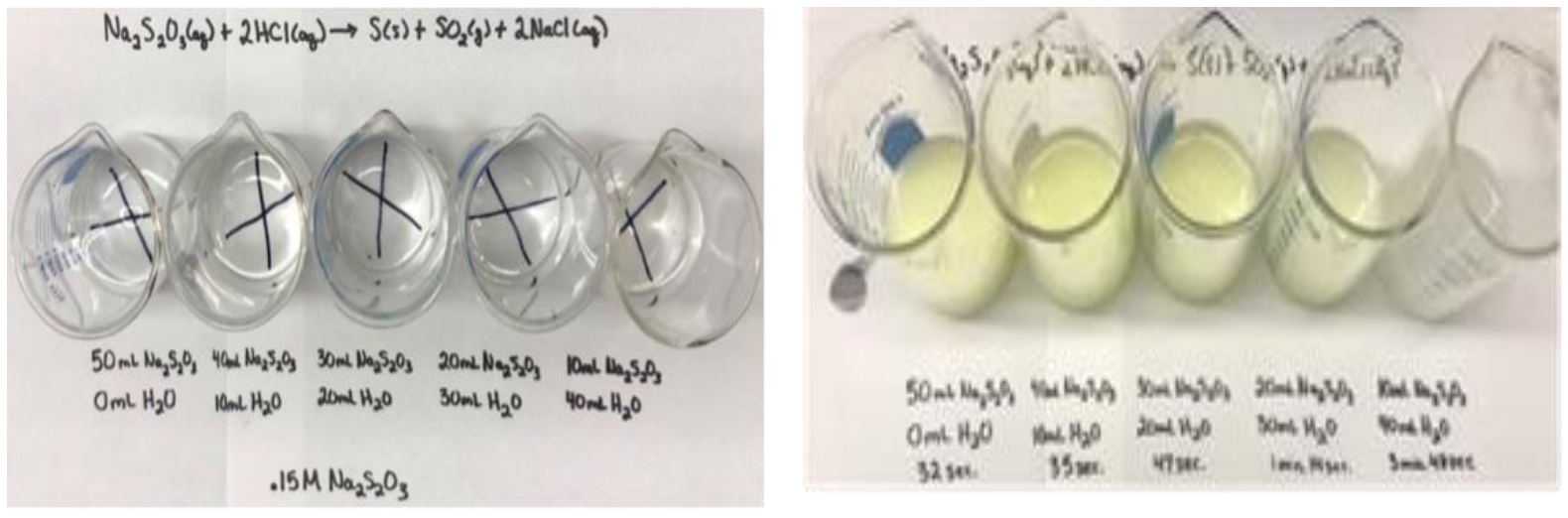
To test the knowledge of students within the framework of intermediate control, one can use the developed electronic test questions in chemistry.

Thus, in the process of teaching the discipline "General and inorganic chemistry" implemented the use of information communication technologies at all stages of education. These are electronic presentations at lectures and practical classes, and special calculation programs for solving problems, and electronic laboratory work, and computer tests before laboratory work and for intermediate control, and methodological and reference materials in electronic form. All these modern forms of education are organically combined with traditional ones (experimental laboratory work, traditional forms of testing, etc.). All this undoubtedly contributes to the successful mastering of the discipline by future engineers and the creation of a solid foundation for their study of special subjects.

\section{REFERENCES:}

1. Gureev N.G. On the use of computer technology in the course of physical chemistry / N.G. Gureev, G.I. Zorina, I.E. Kozhevnikov // News Volgograd State Technical University. 2004. - № 8. - PP. 95-96.

2. Goncharenko E.E. Innovations in technology teaching "Physical and Colloid Chemistry" for students of "Industrial Ecology" (bachelors) / E.E. Goncharenko A.M. Golubev, B.S. Ksenofontov // Engineering Journal: science and innovation. 2013. № 6 (18). - P. 4.

3. Anisova T.L. Solution of problems of physical chemistry by using MS EXCEL / T.L. Anisova, S.I. Salpagarov // Modern problems of science and education. 2012. - № 3. P. 417.

4. Zhukova N.V. The possibility of using electronic test simulators for teaching physical chemistry / N.V. Zhukova // Fundamental research. 2013. - № 10-12. PP. 2778-2781.

5. Kurunina G.M. Using computer technology to assess the quality of knowledge in the course "Physical Chemistry" / G.M. Kurunina, G.I. Zorina, G.M. Casks, A.V. Sinkov, I.E. Zvereva // International Journal of Experimental Education. 2012. - № 1. - P. 95.

6. Bondareva G.M. The use of testing as a form of control of students' knowledge in physical chemistry / G.M. Bondareva // Advances in chemistry and chemical technology. 2012 - T. 26. - № 10 (139). - PP. 43-47.

7. Stepanovskikh E.I. Physical chemistry. Electronic training complex EUMK 10780 [electronic resource] / E.I. Stepanovskikh. Mode of access: http://study.urfu.ru /view/aid_view.aspx?AidId=10780 (date accessed 09.08.2014).

8. Stepanovskikh E.I. Brusnitsyna L.A., Alekseeva T.A. Physical chemistry. Examples of problem solving: a teaching manual [electronic resource] / E.I. Stepanovskikh., L.A. Brusnitsyna, Alekseeva T.A. Mode of access: http://study.urfu.ru/view/aid_view. aspx?AidId=12277 (date accessed 10.08.2014).

9. Bulatov N.K., Stepanovskikh E.I. Physical chemistry. Experience in solving problems on the Russian student competitions [electronic resource] / N. Bulatov, E.I. Stepanovskikh. Mode of access: http: //study. urfu.ru /view/aid_ view.aspx? AidId=8471 (date accessed 10.08.2014). 
10. Stepanovskikh E.I. Multicomponent homogeneous systems / workshop to electronic laboratory work [electronic resource] / E.I. Stepanovskikh. Mode of access: http://study.urfu.ru/view/aid_view.aspx?AidId=9540 (date accessed 10.08.2014).

11. Atqiyayeva S.I., Komilov K.U. Developing intellectual capabilities of students in teaching chemistry. // International scientific and educational electronic journal "Education and Science in the XXI century". 2021, Issue No. 10 (volume 3). - PP. 684-692.

12. Badalova S.I., Komilov Q.U., Kurbanova A.J. Case technology in chemistry lessons. // Academic Research in Educational Sciences. 2020, - Vol. 1. - No. 1. - PP. 262-265.

13. Badalova S.I., Komilov Q.U., Kurbanova A.J. Intellectual training of students of technical institute. // Academic Research in Educational Sciences. 2020. - Vol. 1. - No. 1. PP. 266-274.

14. Shayzakova D.A., Nasimov A.M. Kimyo fanini o'qitishda interfaol usullardan foydalanish // SamDU Ilmiy axborotnoma. 2020-yil, 6-son (124). - B. 106-109.

15. Shaizakova D.A. Kimyo fanini Citishda shahsiy insonparvarlik tekhnologiya sidan foydalanish. // Academic research in educational sciences, 2021.2-sleep (4). B. 603-612.

16. Rustamova H., Kurbanova A.J., Komilov K.U. The role of information and communication technologies in teaching general and inorganic chemistry. // "Economy and society". 2021. - No. 5. (84).

17. Yadgarov B. Komilov K.U., Kurbanova A.Dj. Applying ICT for improvement general chemical education. // Society and innovations. 2021. - №4. - PP. 257-261. 